\title{
FIRST RECORD OF PODICHNUS IN BYRONID SHELL FROM THE LOWER DEVONIAN (PRAGIAN) OF THE PRAGUE BASIN, CZECHIA
}

\author{
Michal Mergl
}

Centre of Biology, Geosciences and Environmental Sciences, Faculty of Education, University of West Bohemia in Plzeň, Klatovská 51, Plzeň, 306 19, Czech Republic; mmergl@cbg.zcu.cz

\begin{abstract}
Brachiopod etching trace Podichnus, typically with centrifugally arranged clusters of holes or slits, has hitherto been known only in calcium carbonate substrates. The similar etching trace is newly described on calcium phosphate substrate. The trace Podichnus isp. in a wall of a phosphatic byronid test was observed in the lower Devonian Vinařice Limestone (Pragian) in the Koněprusy area of the Prague Basin in the Barrandian area, the Czech Republic. The trace is smaller that majority of described species of this fixichnia, and displays a smooth central disc surrounded by two circlets of holes or pits. Some holes penetrate through wall of byronid test without any biotic response of a byronid. The maker of Podichnus isp. is uknown but among the associated fossils are eligible candidates including rhynchonellids, orthids and terebratulids. It is rare direct evidence of etching activity of the pedicle in the Lower Palaeozoic and the first finding of Podichnus in the Devonian in the Prague Basin. The emended diagnosis of the ichnogenus is presented herein.
\end{abstract}

Key words: Podichnus, byronid, brachiopod, calcium phosphate, fixichnia, Devonian, Barrandian area, Prague Basin

\section{INTRODUCTION}

Most extant rhynchonellate brachiopods are attached to firm substrate by the pedicle and the same mode of life is suggested for many of their Palaeozoic ancestors (Rudwick 1970). Ekman (1896) observed that the pedicle of some extant brachiopods may split into rootlets which are able to penetrate into calcium carbonate substrates. Rootlets left characteristic etching traces. These have been firstly recognized on fossil material and named Podichnus centrifugalis by Bromley \& Surlyk (1973). They examined this ichnofossil on surface of brachiopods, oysters and belemnites of Upper Cretaceous age. Subsequently, Podichnus was studied by more authors (Nekvasilová 1975, Michalík 1977, Vogel et al. 1987, Hanger 1992, Schmidt 1992, Reich \& Frenzel 2002, Bromley 2003, Blissett \& Pickerill 2004, Radley 2004, Försterra et al. 2005, Žítt et al. 2006, Jagt et al. 2007, Sørensen \& Surlyk 2008, Breton et al. 2017). Robinson \& Lee (2008) presented a review of todate known Podichnus and associated brachiopods. In their table no older than the Middle Triassic Podichnus is listened (Malkowski 1975), although in the text they noted that Podichnus is known on Silurian rhynchonellid brachiopod (Alexander 1994). Apart of the redefinition of Podichnus centrifugalis these authors described two new ichnospecies, P. obliquus and P. perpendicularis. All examined traces were associated with terebratulid or rhynchonellid brachiopods and leaved characteristic attachment scars. The Lower Ordovician Podichnus conicus was described by Santos et al. (2014). They observed clusters of shallow conical pits in surface of orthid brachiopods Notorthisina musculosa, Nanorthis bifurcata, and Lipanorthis santalaurae, all from the Saladillo Formation of Tremadocian age from Salta Province, Argentina. This hitherto oldest record of Podichnus provides evidence that orthide brachiopods were able to generate this etching trace.

New find of Podichnus on the surface of byronid tube from the Devonian of the Prague Basin, Czechia, provides the evidence of ability of rootlets to etch not only carbonatic substrates as suggested in original (Bromley \& Surlyk 1973) and redefined diagnoses (Robinson \& Lee 2008) but also phosphatic substrates. 


\section{GEOLOGICAL AND PALAEONTOLOGICAL SETTINGS}

The weakly folded Devonian of the Barrandian area (Teplá-Barrandian unit) is confined to the central part of the infill of the Prague Basin (Havlíček 1981, 1998) in Czechia. It is characterized by two major lithofacies: shallow water biodetrital mostly crinoidal limestones which also comprise reefal bioskeletal accumulations of Pragian and, in limited extent, also Emsian and Eifelian age, and more pelagic lithofacies that is represented mostly by calcisiltites (Chlupáč 1998, Slavík \& Hladil 2020). The overlying Givetian siliciclastic succession terminates the entire Ordovician to Middle Devonian volcano-sedimentary infill of the Prague Basin as a reflection of the Variscan orogeny (Vacek \& Žák 2019).

This area was extensively studied since half of $19^{\text {th }}$ century. To present, number of publications on stratigraphy and palaeobiology of the area is enormous. More or less complete survey of principal publications was given by several authors, the best by Chlupáč (2003).

The described specimen was sampled in a small collectors pit at the upper edge of abandoned quarry near Oujezdce northwest of Vinařice in the
Koněprusy area (Havlíček \& Vaněk 1998) (Fig. 1). This locality is famous for rich fauna of the Vinařice Limestone, the member of the Praha Formation (Pragian). The Vinařice Limestone are built of reddish bioclastic and biomicritic limestones which represent transitional (lateral) facies between reef Koněprusy Limestone and relatively deeper Dvorce-Prokop and allied Reporyje, Slivenec and Loděnice limestones of Pragian age (Chlupáč 1998). The fauna in the Oujezdce locality exhibits clear influnce of the Koněprusy reef, yielding diverse and abundant macrofossils, mainly rhynchonelliform brachiopods and proetid trilobites (Havlíček \& Vaněk 1998).

\section{MATERIAL AND PRESERVATION}

Podichnus etching trace was observed on a minute fragment of byronid tubular test, which was released from $20 \mathrm{~kg}$ rock sample of the Vinařice Limestone by its processing by $15 \%$ solution of acetic acid. The residue was washed by clean water and dried. The unique fragment was picked up from residue under binocular microscope and has been glued to hard stab. Compared with other small fossils, fragments of byronid test and their attachment disc (Phosphannulus sp.) are rare in

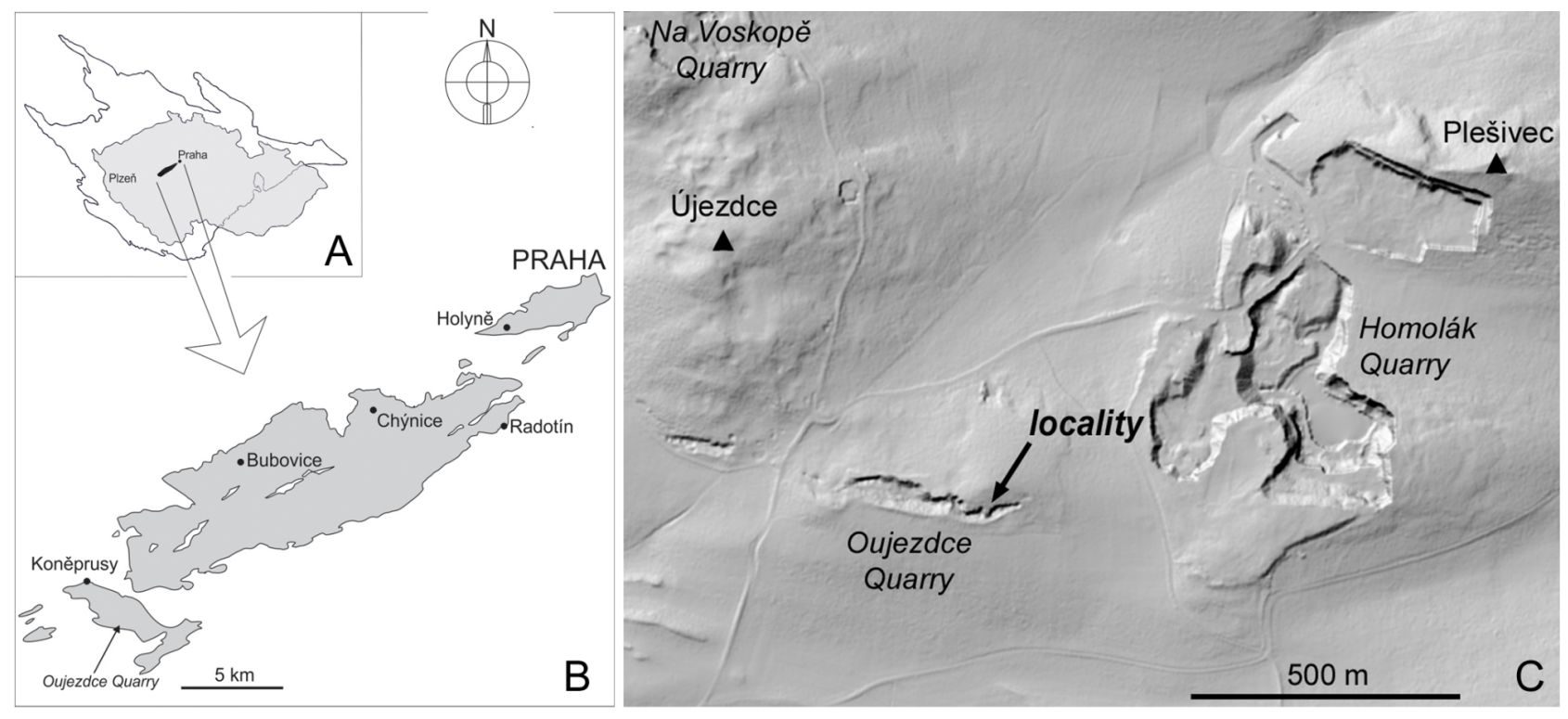

Figure 1. A - Sketch map showing the location of the Devonian of the Prague Basin (black shaded) situated on the territory of the Czech Republic (gray shaded), south-west of Praha, and in the central Bohemian Massif (countoured white area). $B$ - Detail of the Devonian denudation relic with marked locality. C - Vicinity of the locality with quarry in the Vinarice Limestone (Oujezdce quarry) and quarries in the Koněprusy Limestone (Na Voskopě and Homolák quarries) (modified after https://ags.cuzk.cz/geoprohlizec/?p=22517). 
the residue. Unlike to byronids (under study at present), the conodonts, organophosphatic brachiopods, spinose bars of conulariid tests, Eurytholia sclerites, and tiny partly silicified mollusc shells are moderately common in the residue.

The specimen (PCZCU 2486) is stored in the palaeontological collections of the West Bohemia University at Plzeň.

\section{SYSTEMATIC PART}

Ichnogenus Podichnus Bromley \& Surlyk, 1973

Type ichnospecies: Podichnus centrifugalis Bromley \& Surlyk, 1973; Upper Cretaceous, Campanian; England.

Remarks: Following the diagnosis of Robinson \& Lee (2008), the diagnosis of ichnogenus Podichnus
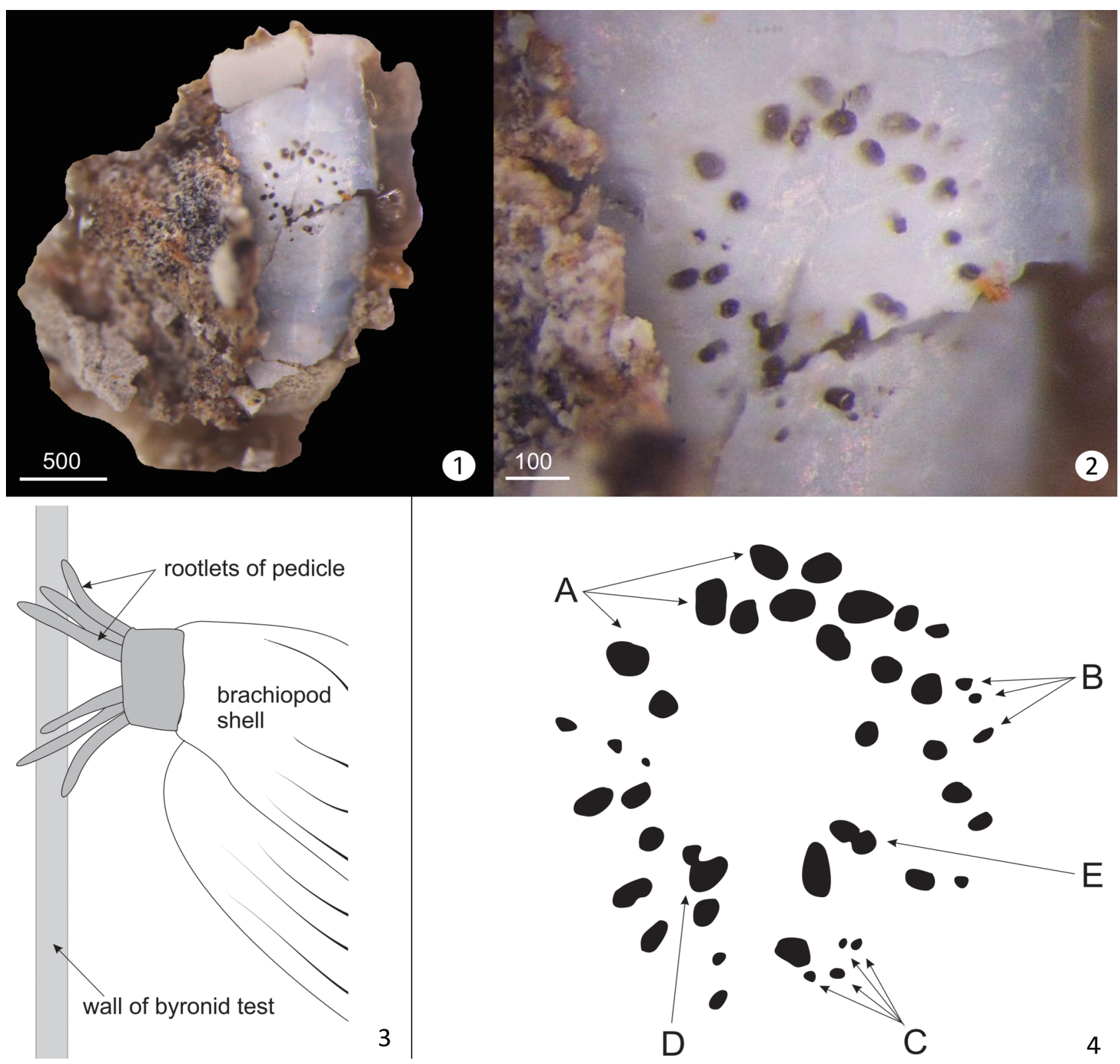

Plate I Podichnus isp., specimen PCZCU 2486; Vinařice Limestone, Pragian; collectors pit above edge of abandoned Oujezdce quarry, Koněprusy area. 1 - Entire byronid fragment with the etching trace. 2 - Detail of the etching trace. 3 - Diagrammatic reconstruction of rootlets arrangement in the byronit test; note centripetal perforating and centrifugal shallowly penetrating rootlets. 4 - Drawing of the etching trace with holes perforating the byronid wall (A), shallow holes and pits which do not perforate the byronid wall (B, C), and two couples of holes (D, E). Length of bars in $\mu \mathrm{m}$. 
is amended herein to include the pedicle attachment scars also with non-carbonate substrate.

Emended diagnosis: More or less compact group or cluster of short pits, holes, elongate cylindrical shafts and/or furrows, mutually paralell or diverging, within carbonate or phosphate substrates. Surface expression is a ca. 1-4 millimetre-sized cluster of holes each up to ca. $200 \mu \mathrm{m}$ in diameter.

\section{Podichnus sp.}

Pl. 1

Description: A cluster of 44 closely spaced holes or pits forms a slighly irregular circle on a subplanar surface of byronid tubular test. The circle is 525 $\mu \mathrm{m}$ long and $450 \mu \mathrm{m}$ wide, leaving a smooth central space of approximately $300 \mu \mathrm{m}$ x $200 \mu \mathrm{m}$ size. Holes have centrifugal arrangement and form two loosely defined circlets (Pl. 1, fig. 2). Holes in external circle have maily oblique outlines, with larger diameter up to $50 \mu \mathrm{m}$. The elongate outline is apparently caused by the intersection of an obliquelly inclined rootlet and a subplanar surface of byronid test (Pl. 1, fig. 3). Holes in inner circle have smaller diameters (20 to $30 \mu \mathrm{m}$ ) and subcircular to regularly circular outlines. This difference indicates that rootlets of inner circle were more or less perpendicular to the surface of byronid test, and the diameter of particular hole pretty corresponds to a diameter of rootlet. Estimated depth of holes ranges between 20 to $50 \mu \mathrm{m}$. The holes have gently conical shape. This is evident from a smaller diameter of hole opening on the inner surface of byronid test wall. At least half of holes has opening on internal surface of the byronid test (Pl. 1, fig. 4, arrow A). That corroborates rootlets penetrations through byronid wall, but there are not any traces of biotic response of the byronid animal to that penetration. Some peripheral etching traces are shallow and only superficial having subelliptical outline in a centrifugal spacing (Pl. 1, fig. 4, arrows B and C). Two paired holes (Pl. 1, fig. 4, arrows $\mathrm{D}$ and $\mathrm{E}$ ) indicate tight grouping of rootlets.

Remarks: The attachment scar demonstrates some characteristic features of Podichnus: the centrifugally arranged circular to elliptical distally tapering holes, but size of observed Podichnus isp. is near lower size limit in the diagnosis of genus (Robinson \& Lee 2008). There are other differences. Unlike to other described brachiopod etching traces, Podichnus isp. has smooth central disc which is devoid of holes and is clearly demarcated by a ring of holes. Another difference seems even more significant. While in all previously described Podichnus etching traces the rootlets or papillae penetrate into substrate of calcium carbonate in brachiopod shells (calcite), mollusc shells (calcite and/or aragonite), echinoderm occicles (Mg-calcite) and scleractinian corals (aragonite), the byronid test is composed from calcium phosphate. Despite these differences the observed trace is referred to Podichnus. Its uniqueness makes erection on new ichnospecies purposeless and emendation of the ichnogenus diagnosis is preferred herein.

\section{DISCUSSION}

Podichnus sp. was observed in the byronid test of unnamed species, which differs chemico-structurally from hitherto described substrates demonstrating Podichnus etching traces. Previous observation indicates (Bischoff 1989, Holmer 1987, Malinky et al. 2004) that tests of byronids have sandwich-like structure and are mineralised by a calcium phosphate: the compact laminae regularly alternate with the laminae showing vacant interspaces between columnar crystallites of apatite. One may anticipate that these intespaces were likely filled by an organic matter and provided moderate flexibility to byronid test. Exact structure of the byronid test bearing Podichnus isp. is uknown, but likely does not significantly deviate from structure and composition of other byronids of the Devonian age (Bischoff 1989; Mergl \& Kraft, unpublished). The thickness of the wall centripetally increases with byronid size and decreases towards its aperture. The walls of the elaborately examined byronid Prestephanoscyphus sp. from the Lochkov Formation (Lochkovian, Prague Basin), which is most likely an evolutionary forerunner of the byronid with Podichnus isp., may have only $10 \mu \mathrm{m}$ thick wall but the thicknes may increase to $30 \mu \mathrm{m}$ or more in the proximal part of test. The byronid test likely represented a sufficently solid substrate for firm attachment of small pedunculate brachiopod.

There are more candidates for a maker of Podichnus isp. from the Oujedce locality. Some rhynchonelliform species, likely a small immature individual, is probable maker of the etching trace. 
However, assessment to particular taxon is speculative. Apart of more small rhynchonellid species (genera Astutorhyncha, Corvinopugnax, Eoglossinotoechia, Kotysex; see Havlíček \& Vaněk 1998), small orthids Resserella or Dalejina, or a terebratulid Cryptonella melonica may be anticipated. However, the 10 to $20 \mathrm{~mm}$ long byronid test would not be adequately stable substrate for larger pedunculate brachiopods. Many brachiopod clades (strophomenoids, chonetoids) may be excluded because preferred a different non-pedunculate life habit. However, cannot be excluded, that rootlets emerging from brachiopod pedicle penetrated to loose bioskeletal debris containing a vacant byronid test.

Etching ability of distal rootlet termination was studied by Mackay \& Hewitt (1978). In the Recent brachiopods the vesicles released from the epithelial cells of the distal rootlets are similar to vesicles of vertebrate osteoclasts. Vesicles released from osteoclasts contain acid phosphatase. Acid phosphatase is lysozomal enzyme that hydrolyses organic phosphates. These vesicles can pass to the extracellular space between the osteoclast and bone, and are responsible for remodelation of a bone. Mackay \& Hewitt (1978) suggest similar ability for resorpion of skeletal material by the rootlets of brachiopod pedicle. Podichnus isp. in the byronid test indicates that the same etching mechanism which is used by rootled epithelium for destruction of a calcium carbonate shell was efficient in calcium phosphate substrates.

\section{CONCLUSION}

Discovery of Podichnus isp. in the byronid test released from the Vinarrice Limestone (Lower Devonian) provides the first evidence on etching ability of brachiopod pedicle rootlets on a calcium phosphate substrate. This etching trace suggests that even a tiny objects erected above sea floor were occasionally used as the firm substrate for pedicle attachment of small rhynchonelliformean brachiopods.

Apparent ability to dissolve calcium phosphate substrates could initiate seeking of Podichnus ichnospecies in other phosphatic but formerly ignored substrates: epibentic linguliform brachiopods, byronids, and conulariids in the Palaeozoic, and vertebrate bones, scales and teeth in post-Silurian marine deposits.

\section{ACKNOWLEDGEMENTS}

This paper was financially supported by a grant from the Czech Science Foundation GA18-05935S.

I am grateful to O. Vinn (Estonia) and the anonymous reviewer for valuable comments on draft of the manuscript.

\section{REFERENCES}

Alexander, R.R. 1994. Distribution of pedicle boring traces and the life habit of Late Paleozoic leiorhynchid brachiopods from dysoxic habitats. Lethaia 27, 227-234.

Bischoff, G.C.O. 1989. Byroniida, new order, from early Palaeozoic strata of eastern Australia (Cnidaria, thecate scyphopolyps). Senckenbergiana Lethaea 69, 467-521.

Blissett, D. \& Pickerill, R.K. 2004. Aspects of micro- and macroborings from the White Limestone Group, Jamaica, West Indies. Geological Society of America Abstracts with Programs 36, 111.

Breton, G., Wisshak, M., Néraudeau, D. \& Morel, N. 2017. Parasitic gastropod bioerosion trace fossil on Cenomanian oysters from Le Mans, France and its ichnologic and taphonomic context. Acta Palaeontologica Polonica 62(1), 45-57.

Bromley. R.G. 2003. Bioerosion of Pleistocene Lophelia, Rhodes, Greece, 24. In Freiwald, A. \& Schlubert, C. (eds) 2nd International Sympozium on Deep-sea Corals, September $8^{\text {th }}-13^{\text {th }} 2003$, Erlangen. Erlanger geologische Abhandlungen, Sonderband 4.

Bromley, R.G. \& Surlyk, F. 1973. Borings produced by brachiopod pedicles, fossil and recent. Lethaia 6, 349-365.

Chlupáč, I. 1998. Devonian, 101-133 In Chlupáč, I., Havlíček, V., Kříž, J., Kukal, Z. \& Štorch, P. (eds) Palaeozoic of the Barrandian (Cambrian to Devonian). Czech Geological Survey, Prague.

Chlupáč, I. 2003. Comments on facies development and stratigraphy of the Devonian, Barrandian area, Czech Republic, Bulletin of Geosciences 78, 299-312.

Ekman, T. 1896. Beiträge zur Kenntnis des Stieles der Brachiopoden. Zeitschrift für wissenschaftliche Zoologie 62, 169-249.

Försterra, G., Beuck, L., Häusermann, V. \& Freiwald, A. 2005. Shallow-water Desmophyllum dianthus (Scleractinia) from Chile: characteristics of the biocoenoses, the bioeroding community, heterotrophic interaction and (paleo)-bathymet- 
ric implications, 937-977. In Freiwald, A. \& Roberts, J.M. (eds) Cold-water corals and ecosystems. Springer Verlag, Berlin/Heidelberg.

Hanger, R.A. 1992. Podichnus centrifugalis (Bromley and Surlyk, 1973) in the Cretaceous (Albian) Dick Creek Formation, Tarrant County, Texas. Texas Journal of Science 44, 252-254.

Havlíček, V. 1981. Development of a linear sedimentary depression exemplified by the Prague basin (Ordovician-Middle Devonian; Barrandian area-central Bohemia). Sborník geologických věd, Geologie 35, 7-48.

Havlíček, V. 1998. Prague Basin, 39-41. In Chlupáč, I., Havlíček, V., Kř́žn, J., Kukal Z. \& Storch, P. (eds) Palaeozoic of the Barrandian (Cambrian to Devonian). Czech Geological Survey, Prague.

Havlíček, V. \& Vaněk, J. 1998. Pragian brachiopods, trilobites, and principal biofacies in the Prague Basin (Lower Devonian, Bohemia). Sborník geologických věd, Paleontologie 34, 27-109.

Holmer, L.E. 1987. Ordovician mazuelloids and other microfossils from Västergötland. Geologicka Föreninges $i$ Stockholm Förhandlingar 109(1), 67-71.

Jagt, J.W.M., Dortangs, R., Simon, E. \& Van Knippenberg, P. 2007. First record of the ichnofossils Podichnus centrifugalis from the Maastrichtian of northeast Belgium. Bulletin de l'Institut Royal des Sciences Naturelles de Belgique, Science de la Terre 77, 93-105.

Mackay, S. \& Hewitt, R.A. 1978. Ultrastructural studies on the brachiopod pedicle. Lethaia 11, 331-339.

Malinky, J.M., Wilson, M.A., Holmer, L.E. \& Lardeux, H., 2004. Tube Shaped Incertae Sedis. Byroniids, 220-221. In Webby, B.D., Paris, F., Droser, M.L. \& Percival, I.G. (eds) The Great Ordovician Biodiversification Event. Columbia University Press, New York.

Malkowski, K. 1975. Attachment scars of the brachiopod Coenothyris vulgaris (Schlotheim 1820) from the Muschelkalk of Upper Silesia. Acta Geologica Polonica 25, 275-283.

Michalík, J. 1977. Systematics and ecology of Zeilleria Bayle and other brachiopods in the uppermost Triassic of the West Carpathians. Geologica Carpathica 28, 323-346.

Nekvasilová, O. 1975. The etching traces produced by pedicles of Upper Cretaceous brachiopods from Bohemia (Czechoslovakia). ¿̌asopis pro mineralogii a geologii 28(1), 23-30.

Radley, J.D. 2004. Brachiopod pedicle attachment scars (Podichnus centrifugalis Bromley \& Surlyk) on Lower Jurassic oysters (Gloucestershire and Warwickshire). Proceedings of the Cotteswold Naturalists' Field Club 43, 18-19.

Reich, M. \& Frenzel, P. 2002. Die Fauna und Flora der Rügener Schreibkreide (Maastrichtium, Ostsee). Archiv für Geschiebekunde 3, 73-284.

Robinson, J.H. \& Lee, D.E. 2008. Brachiopod pedicle traces: recognition of three separate types of trace and redefinion of Podichnus centrifugalis Bromley \& Surlyk, 1973. Fossils and Strata 54, 219-225.

Rudwick, M.J.S. 1970. Living and Fossil Brachiopods. Hurchinson \& Cp. Lts., London, 199 pp.

Santos, A., Mayoral, E., Villas, E., Herrera, Z. \& Ortega, G. 2014. First record of Podichnus in orthide brachiopods from the Lower Ordovician (Tremadocian) of NW Argentina and its relation to the early use of an ethological strategy. Palaeogeography, Palaeoclimatology, Palaeoecology 399, 67-77.

Schmidt, H. 1992. Mikrobohrspuren ausgewälther Faciesbereiche der tethyalen und germanischen Trias (Beschreibung, Vergleich und bathymetrische Interpretation). Frankfurther geowissenschftliche Arbeite A12, 1-228.

Slavík, L. \& Hladil, J. 2020. Early Devonian (Lochkovian-early Emsian) bioevents and conodont response in the Prague Synform (Czech Republic). Palaeogeography, Palaeoclimatology, Palaeoecology 549, 109148.

Sørensen, A.M. \& Surlyk, F. 2008. A brachiopod boring (Podichnus) in a Late Cretaceous oyster from a mangrove-like environment, Skane, Sweden. Lethaia 41(3), 295-298.

Vacek, F. \& Žák, J. 2019. A lifetime of the Variscan orogenic plateau from uplift to collapse as recorded by the Prague Basin, Bohemian Massif. Geological Magazine 156(3), 485-509.

Vogel, K., Golubic, S. \& Brett, C.E. 1987. Endolith associations and their relation to facies distribution in the Middle Devonian of New York State, USA. Lethaia 20, 263-290.

Žítt, J., Vodrážka, R., Hradecká, L., Svobodová, M. \& Zágoršek, K. 2006. Late Cretaceous environments and communities as recorded at Chrtníky (Bohemian Cretaceous Basin, Czech Republic). Bulletin of Geosciences 81(1), 43-79. 